\title{
TWO FINNISH GIRLS AND MATHEMATICS: SIMILAR ACHIEVEMENT LEVEL, SAME CORE CURRICULUM, DIFFERENT COMPETENCES
}

\author{
Hanna Viitala \\ Department of Mathematical Sciences, Faculty of Engineering and Science, University of Agder • \\ hanna.l.viitala@uia.no
}

\begin{abstract}
Mathematical thinking and problem solving are essential parts of learning mathematics described in the Finnish National Core Curriculum for Basic Education. Evaluations on both have been done at national and international level. However, in a request for deeper understanding of pupils' mathematical thinking we need to move beyond paper tests. This paper is a first look into the mathematical thinking of two Finnish girls, Emma and Nora, in their final year of Finnish comprehensive school. After solving a real-life situated problem in a classroom, the girls talk about mathematics and problem solving in an interview. The focus of the analysis is on the learning objectives, core content and final-assessment criteria related to thinking skills and methods in the Finnish curriculum. Also some results on metacognition and affect will be reported. The results suggest that while both pupils have similar achievement level in mathematics, their competences are different: Emma is more competent in problem solving and Nora is more self-confident and selfguided in learning mathematics and can more easily recognize mathematics outside school.
\end{abstract}

\section{Introduction}

The Finnish National Core Curriculum for Basic Education has three tasks for mathematics instruction: developing mathematical thinking, learning mathematical concepts, and learning most widely used problem solving methods (FNBE, 2004). All these instructional tasks are evaluated near the end of comprehensive school at local, national (e.g. Rautopuro, 2013; Hirvonen, 2012) and international (e.g. OECD, 2014; Mullis, Martin, Foy \& Arora, 2012) level. While Finland continuously stays among top countries in PISA assessments, most recent studies show how the level of mathematical skills is declining (Välijärvi, 2014; Rautopuro, 2013; Hirvonen, 2012). To better understand the situation with mathematical thinking, more research going beyond paper tests is needed. For this aim, in this research project we move closer to the pupils and ask: What characterises mathematical thinking of Finnish pupils at the end of comprehensive school?

Part of the general mission of basic education is to offer pupils opportunities to obtain 'the knowledge and skills they need in life, [and] become capable of further study' (FNBE, 2004, p. 12). Real-life connections are highlighted also in mathematics learning objectives, and the national curriculum emphasizes that instruction should utilize effectively problems that come up in day-to-day situations (ibid.). To study mathematical thinking of 15-yearolds, we need concrete tools (tasks or problems) to be able to talk about mathematics and mathematical thinking. PISA assessment offers well-tested mathematical problems designed for 15-year-olds that are based on real-life situations. Choosing tasks that move beyond the kinds of situations and problems that are typically encountered in school 
classrooms (OECD, 2009) we aim to interpret what kind of mathematical thinking pupils enter the world outside school with.

This paper is a step towards understanding Finnish pupils' mathematical thinking better. Problem solving is an important part of mathematical thinking and serves as a starting point for the analysis. The focus in this paper is on the learning objectives, core content and final-assessment criteria related to (mathematical) thinking skills and methods in the Finnish Core Curriculum for Basic Education (FNBE, 2004). In addition to cognitive and metacognitive aspects of the curriculum, also some affective aspects will be discussed.

The paper aims to answer the following questions:

What characterizes the problem solving of two Finnish girls solving a PISA task?

a. What similarities and differences can be found in their problem solving?

b. How do the results reflect the learning objectives, core content and final-assessment criteria of 'thinking skills and methods' described in the Finnish curriculum?

\section{Theoretical framework}

The key concept in the research project is mathematical thinking. Despite its wide use in the literature, there is no common understanding of what is meant by mathematical thinking (e.g. Sternberg, 1996; Burton, 1984). With difficulties in defining the term most studies adopt a practical view, without framing the concept, focusing on questions like how mathematical thinking can be measured or improved in school (e.g. McGregor, 2007; Doerr, 2006), or what kind of mathematical thinking do students have (in Finland e.g. Hähkiöniemi, 2006; Joutsenlahti, 2005). Here, thinking is considered being mathematical when it relies on operations that are mathematical in separation of thinking about the subject matter of mathematics (Burton, 1984). Furthermore, pupils' activities, actions and explanations during problem solving are interpreted as visible signs or expressions of their mathematical thinking. In the following, the three aspects of mathematical thinking that are discussed in this paper will be introduced. These are problem solving, metacognition and affect.

\subsection{Problem solving}

Problem solving is an essential part of, and thus an important tool in understanding pupils' mathematical thinking. Since both terms 'problem' and 'problem solving' have many meanings in mathematics education (Törner, Schoenfeld \& Reiss, 2007), they need clarification. Here, mathematical task is called a problem if the solver has to combine previously known data in a new way to her to solve a task (e.g. Kantowski, 1980). Furthermore, with problem solving we refer to the activities and actions pupils perform while solving a given mathematical task or a problem.

In the present paper we want to emphasize the problem solving phases that the Finnish curriculum lists in its final-assessment criteria of thinking skills and methods for a grade of 
8 (FNBE 2004). These phases are transforming a text problem to a mathematical form of presentation, making a plan to solve a problem, solving it, and checking the correctness of the result. These phases follow the problem solving principles described by Polya (1957). Transforming text to mathematical presentations requires understanding the problem, and further, checking the results is a part of looking back (cf. ibid.).

\subsection{Metacognition}

When studying pupils' mathematical thinking, especially through problem solving, also their metacognitive skills should be recognized. Similarly as terms 'problem' and 'problem solving', also 'metacognition' has many different meanings in educational research (Stillman \& Mevarech, 2010). In 1987 Schoenfeld (1987, p.190) listed three aspects of research on metacognition: 'your knowledge about your own thought processes', 'control or self-regulation', and 'beliefs and intuitions'. Even though theories on metacognition has been developed since (Stillman et al., 2010), the three aspects of metacognitive research (Schoenfeld, 1987) give a useful starting point for studying of pupils' metacognition in problem solving.

Also the Finnish curriculum (FNBE, 2004) lists some metacognitive factors in learning objectives for sixth to ninth graders. According to the curriculum, pupils should 'learn to trust themselves, and to take responsibility for their own learning in mathematics' and 'learn to work in a sustained, focused manner, and to function in a group' (ibid., p. 164). Excluding group work, findings of the above mentioned learning objectives will be discussed.

\subsection{Affect}

When studying pupils' mathematical thinking, research has usually concentrated purely on the cognitive aspect (here, problem solving and metacognition). However, it has become clear that if we really want to describe mathematical thinking, we should also relate to affective factors (e.g. Vinner, 2004). One aim of the research project is to understand the interrelationship between affect and cognition (Zan, Brown, Evans \& Hannula, 2006) in mathematical thinking.

Affect is seen as mixture of cognitive, motivational, emotional processes and can be expressed as follows (Hannula, 2012, p. 144):

Cognition deals with information (self and the environment), while motivation directs behaviour (goals and choices). Success or failure in goal-directed behaviour is reflected in emotions (e.g., shame). These emotions, in turn, act as a feedback system to cognitive and motivational processes.

In addition to looking at affect through cognitive, motivational and emotional processes, it also has physiological, psychological and social domains as well as trait and state aspects (Hannula, 2011). The present paper deals affect as a psychological domain and looks at it from both trait and state aspect. Connected to problem solving, rapidly changing affective 
state is in focus. In discussion, also some aspects of more stable affective trait will be discussed.

\section{Methods and methodology}

\subsection{Participants}

The aim of the research project is to study Finnish pupils' mathematical thinking at the end of comprehensive school. Thus, data was collected in the first semester of $9^{\text {th }}$ grade when pupils are 15 years of age. High achieving girls Emma (mathematics grade $9^{1}$ ) and Nora (mathematics grade 10) are from different schools. Similar achievement level is the reason why they were selected for this paper. Additionally they both worked mainly individually with the tasks in the classroom.

\subsection{Data collection}

The data for this paper was collected both from a classroom and from an interview. Emma and Nora solved one PISA task in an ordinary classroom situation. The teacher chose the way she ${ }^{2}$ introduced the task to the whole class and the researcher acted as an observer. Emma and Nora were video recorded when they solved the task and their solutions on paper were collected. Natural classroom setting was used to give the pupils an opportunity to work in a familiar way to them. They were able to ask help from their teacher and peers. It also enabled the researcher to find out what kind of difficulties the pupils faced and how they were accustomed to solve them. Additionally, if the girls talked about the task with someone, the researcher was able to follow their reasoning.

Emma and Nora were interviewed on the same or the following day after solving the PISA task in classroom. The interviews contained two parts. The first part had three themes (see Table 1): pupil's background, mathematics and oneself within mathematics (following Pehkonen, 1995; more about interview themes in the project see Viitala, 2013). This part of the interview was semi-structured and focused (Kvale \& Brinkmann, 2009), focusing on affective components within and towards mathematics.

Table 1 Interview themes and example questions

\begin{tabular}{cc}
\hline Theme & Example questions \\
\hline Background & Tell me about your family. \\
Mathematics & What is mathematics as science? \\
& Does mathematics exist outside school? (How? Where?) \\
Oneself within mathematics & Is mathematics important to you? \\
& Does mathematics help you think logically? (How?) \\
\hline
\end{tabular}

\footnotetext{
${ }^{1}$ On a scale $4-10$.

2 Due to the small amount of participants in the study, all teachers are treated as females to preserve anonymity.
} 


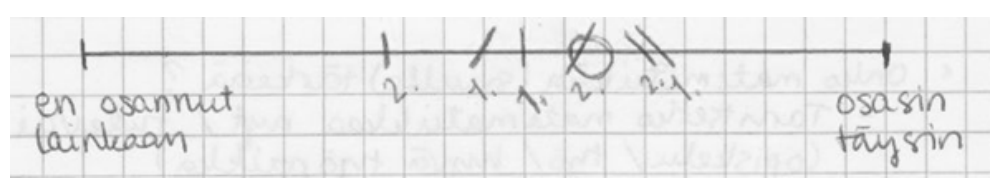

Figure 1 Emma's confidence line from the interview ( 2 tasks). The line is $10 \mathrm{~cm}$ long with a scale from 'I couldn't do it at all' (left) to 'I could do it perfectly' (right). Symbols: Confidence after reading the task $\mid$, while solving the task /, after solving the task $\backslash$, and confidence in school mathematics $\circ$.

The second part of the interview was about problem solving. The classroom video was used as stimuli when the pupil's problem solving phases were discussed. Also the solution paper was used to support the discussion. After the stimulated recall part, some metacognitive (thinking about own thinking) and affective (feelings, motivation) questions concerning the problem solving situation were asked and a $10 \mathrm{~cm}$ long confidence line was introduced (see Figure 1). The pupils used the confidence line to assess their confidence prior, during and after solving the problems as well as their current confidence in school mathematics. Similar estimations of certainty was used e.g. in Merenluoto (2001).

Emma and Nora were interviewed individually by the researcher. The interviews were video recorded. Video camera in classroom was directed towards the pupil's desk showing her work on paper. In the interview, the camera pointed also to the computer from which the classroom video was watched. These settings were chosen to ease the analysis and to preserve anonymity.

\subsection{The PISA task}

The PISA task discussed in this paper is called 'Holiday'. Holiday was chosen from PISA 2003 problem solving survey (OECD, 2006, pp. 77-78). It only requires elementary arithmetical content knowledge so all pupils should master the pure mathematics in the task. Additionally, it has all five aspects of mathematizing present: the problem is situated in reality, the problem solver has to identify the relevant mathematics and reorganise the problem and gradually trim away the reality, solve the mathematical problem and reflect on the mathematical solution in terms of the real situation (ibid., pp. 74-75, 78).

Holiday consist of two tasks both which Emma and Nora solved. The first task is to calculate the shortest route between two towns and the second is to plan where to stay overnight on a holiday trip. A simplified map of the area and a table of distances between towns ${ }^{3}$ are given within the task.

\subsection{Analysis}

The analysis was divided into two sections: Problem solving, and Affect related to mathematics. These titles are somewhat misleading and need elaboration. Principally, both of these sections contain cognitive, metacognitive and affective aspects.

\footnotetext{
3 In the pupils' version of 'Figure B' all grey cells were white (blank). Additionally there is an error in 'Figure B' (corrected in OECD, 2009): The distance between Nuben and Lapat should be 1000, instead of 1300. Neither of the pupils used this information.
} 
In problem solving, the main focus is on the cognitive problem solving process written in the curriculum as final-assessment criteria. After analysing problem solving processes, also some other cognitive aspects from core content and final-assessment criteria of thinking skills and methods will be discussed (e.g. interpreting and producing mathematical texts, and presenting possible alternative solutions systematically). In problem solving, thinking about own thinking as well as control and self-regulation (e.g. keeping track what is being done during problem solving) will be discussed as part of metacognition. Pupil's motivation to solve the tasks as well as feelings and confidence during problem solving will be reported as part of psychological affective state.

In affect related to mathematics, pupils' view on mathematics and connections between mathematics and real life will be reported. Discussion on metacognition concentrates on the metacognitive aspects listed in learning objectives in the curriculum (e.g. trusting oneself). From affect, some aspects of relatively stable psychological trait will be discussed (e.g. feelings and beliefs towards and within mathematics).

\section{Results}

This chapter starts with describing the problem solving phases of Emma and Nora. In chapter 4.1, classroom and interview data are combined and some metacognitive and affective data is included. When summarizing problem solving results in chapter 4.1.3, some interpretations of the problem solving results, and other aspects of thinking skills and methods from the curriculum will be examined and reported. Finally, aspects of affect related to mathematics will be discussed in chapter 4.2. These results are based on the interviews.

\subsection{Problem solving}

\section{Emma}

\section{Task 1}

Emma read through and thought about the first task for almost six minutes before starting to solve it. The task felt easy for her in the beginning but the atypical table (Figure B in OECD, 2006, p. 77) made her feel nervous. Because she had difficulties in understanding the table in the first task, she also read the second task before deciding to do the 'easier' first task first.

During the six first minutes, Emma says she used most of her time on reflecting the table. She struggled with how to read the table and wondering 'what is the distance'. Also the structure of the table disturbed her: she didn't understand 'the steps', why there is just a line on the bottom right corner, and why Piraz is at the bottom twice. In Emma's words, she panicked and it took her almost five and a half minutes (including a minute long announcement through speakers) to 'really starting to concentrate'. After realizing it is the empty spot in the table she needed to 'do', she made a plan and started to solve the task. 


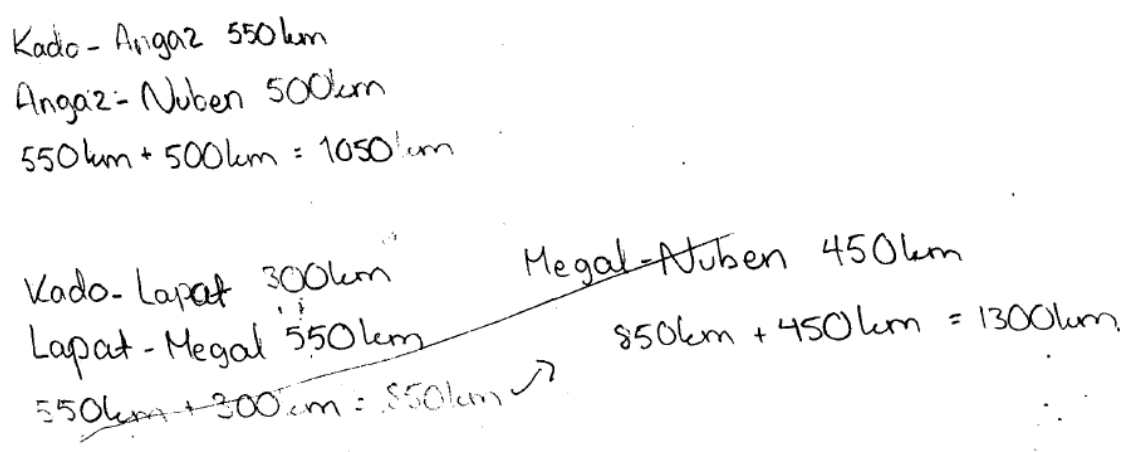

Figure 2 Emma's calculations of task 1

Emma decided which routes to calculate by estimating distances from the map. In addition to the route that seemed shortest to her (Kado-Angaz-Nuben), she decided to calculate another (in her view the second shortest) route (Kado-Lapat-Megal-Nuben) to confirm the result. She did not calculate more routes because they seemed longer than the chosen two. She calculated the route distances proceeding city-by-city, starting with the one that seemed the shortest. Throughout the task solution process, Emma was quick in looking at the distances from the table and moved her pen near the table only twice.

In her calculations Emma was very thorough and wrote everything down neatly step-bystep (see Figure 2). All the calculations she did mentally. Realizing that the task is about doing elementary mathematics made her feel unease. Only once she made a mistake in her calculations and/or writing (writes ' 15 ') which she immediately corrects (erases ' 5 ' and corrects it to '1050'). After calculating the second route, she drew a line over the calculations for that route and wrote the answer ('1050 km') to the answer line. Emma was done with the first task after ten and a half minutes (including the announcement that took a minute from the task).

Emma checked the calculations for the shortest route, not for the longer one. However, it is not clear when she did so (probably during the last minute of working with the tasks when she moves her papers around and also completes her answer to the second task). In addition, she asked her friends if they also got 1050 as an answer to the first task as a confirmation.

Task 2

Emma started the second task by reading it three times. The task felt hard because it had a lot of text'. First she read the task quickly through. On second reading, she marked all the given information to the map. Then she continued thinking how to 'calculate the 300' and realized she needs to use the table (Figure B in OECD, 2006, p. 77). She wrote all the needed distances to the map. Then she read the task for the third time.

After almost three minutes Emma started to solve the task by calculating the overall distance of the trip (' $550 \mathrm{~km}+500 \mathrm{~km}+300 \mathrm{~km}=1350 \mathrm{~km}$ '). In the interview, she could not explain why she calculated it even after thinking about it for quite a while. While she was doing the calculation, the teacher encouraged the class to talk about the tasks with 
friends. So far very silent class got noisy quickly and Emma started talking about the second task with her friends.

First, Emma's classmates talked about how the task should be done. Emma listened the discussion and wrote ' $550 \mathrm{~km}-300 \mathrm{~km}=250 \mathrm{~km}$ ' on paper under the calculated overall distance. Then she asked the girls if she has proceeded correctly and got a confirmation. The discussion continued by one of the girls starting to explain the beginning of the task to Emma. Very quickly Emma took over and started explaining the task to the girl and asking confirmative questions (e.g. 'So I put two nights here in Kado?'). Emma went through the whole task and wrote down the answer as she went on.

While explaining, Emma did not have to go to the task description again; she remembered all the needed details from reading the task. After starting to explain the solution to her friend, it took Emma only a bit more than a minute to finish solving the task. After Emma was done, the teacher walked by and Emma asked her how much she has to justify her thinking on paper. The teacher says it is important to justify so the thinking becomes visible. Emma is concerned about the time, so after asking the researcher they agree that Emma can explain (justify) her thinking in the interview.

In the end, the problem felt easy to Emma. She checked the answer of the second task after working with both tasks and completed it: 'Kado' became 'In Kado' (rows 2 and 3) and 'Lapat' became 'In Lapat' (rows 4 and 5). Then she took the paper to the teacher. The overall time she worked with the two tasks was over eighteen minutes.

\section{Nora}

Task 1

After reading the first task description Nora felt that the task is 'very easy', until she went through the table (Figure B in OECD, 2006, p. 77). She thought that the table did not have all the distances and she felt 'a bit like but not frustrated'. After looking at the table for a while she realized that if she cannot find the distance starting from left, she needs to start from down. Then she made a plan to solve the task. All this took Nora less than one and a half minutes.

Nora decided to calculate one route that seemed to be the shortest (Kado-Lapat-MegalNuben) based on an evaluation from looking at the map. She started to look for the distances city-by-city from the table and write the expression for the calculation as she went on (first distance: ' 300 +'). After getting almost to the end, she faced a problem with finding the last distance from the table. She looked Megal-Nuben from left to down, then NubenMegal from down to left. After that she thought this distance was not in the table and made a new plan for solving the task.

On the second try, Nora went back one distance and decided proceed from there to another direction (aiming to calculate route Kado-Lapat-Angaz-Nuben). She checked the first distance from the table and proceeded with the chosen route. She had her finger on the table pointing at Megal (down) but in the interview she could not remember why. She did 
not use any information from that column. After continuing with the second route Nora faced the same problem again: she could not find the last distance from the table. She had to do yet another plan for solving the task.

Nora erased everything she had written so far and decided to start from the other end of the route (Nuben) and calculate the route she can find the distances to. At this point Nora felt frustrated. She had failed completing two routes already which made her thinking if the task was a trick. Now, she had been working with the task for less than three minutes.

Nora proceeded by looking at the distances she can find from Nuben starting from the bottom row of the table. She found only one distance (Nuben-Piraz), so she started with that. Nora managed to find all distances to the new route (Nuben-Piraz-Angaz-Kado) and made a miscalculation when calculating the overall distance (' $250+300+550=11000$ '). The magnitude of the answer did not seem right, so she went back to the calculation and corrected the answer (see Figure 3). Then she wrote her answer ('1100') to the answer line. At this point Nora had used less than four and a half minutes of her time.

Throughout the task, Nora mostly used her fingers as support when she was looking at the distances from the table. She did not check her answer. However, after Nora had done both tasks, a classmate asked if she had the same answer to the first task as he had. They both had the same answer and Nora got a confirmation.

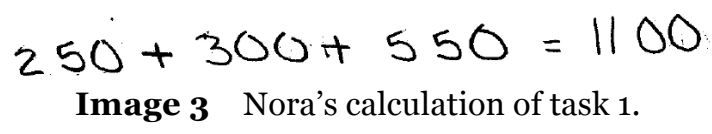

Task 2

Nora did not understand the second task from first reading and she had to read it through 'at least three times'. She began to go through the task step-by-step combining the given information with the map. However, she did not write anything down on the map. She used her finger to point the first town (Angaz) and then the road between the first and the second town (Angaz-Kado). She spent half a minute pointing at the map before starting to solve the task. At this point, Nora had worked with the second task for a bit more than a minute.

Nora began to write something to the answer area (another table, OECD, 2006, p.78) and erased it. The answer area disturbed her. It seemed to her that there is a mismatch with the columns, first one indicating a day and the second one indicating a night. Soon she realized that it has to be the same day after which they spend the night. Even in the interview Nora though that the mismatch should have been corrected so that the time and the place match.

After a half a minute confusion concerning the answer area, Nora wrote answers to the first two rows ('In Kado') and, after a short while, to the next two rows ('Lapat'). Then she was interrupted by a classmate asking her what he should do in the second task. Nora started to help him. 
Nora explained to the classmate the steps needed to get from the first town to the second one (how the towns form 'a ring', there is $500 \mathrm{~km}$ between Angaz and Kado, first camping area is between them, she (girl from the task) can go maximum of $300 \mathrm{~km}$, and so on). After Nora reached the second town in her explanations, the boy repeated what he had learnt and the teacher interrupted them by saying something to the whole class. The discussion with the boy ended and Nora returned to her paper. She started to write down the last step to the answer area (row 6). After writing 'Lapat and Angaz's', the boy interrupted her again asking for help. They went through the rest of the task together similarly as before and Nora did not return to the task again.

Nora did not check her result (which in fact was incomplete). Excluding the time used to help the boy, it took Nora only less than three minutes to solve the second task. Including the given help, Nora used five and a half minutes for the second task and ten minutes for the two tasks together.

\section{Summing up problem solving results}

Emma is a reflective problem solver. She agrees that it is important for her to understand the given information before starting to plan and solve problems. She explains how she can return to the task description even in the middle of calculations to confirm herself that she is doing the right thing. If the problem feels hard, she might try different ways of solving it and choose the one that seems correct (in tests). In the first task she also looked for alternative solution to confirm her result. She also checks her results to the given tasks.

Even though Emma seems fluent in problem solving (following all the steps from the curriculum) and self-regulation, word problems make her feel unease. She originates the dislike of word problems to elementary school where she often failed to solve them. Emma 'always remembers' her father saying: 'Remember to read word problems properly, as many times as needed, think what is asked'. This has helped her face word problems.

Nora is more direct in problem solving. She also wants to understand the problem and the given information before starting to plan and solve problems. If the problem is complicated (as the second task here), she cuts it in smaller pieces to better understand what is given. She explains how she stops to think about the solution only if there is a problem. In the first task, Nora handled problems flexibly and made new plans quickly. She says that she is happy with the first result she gets. Here, she did not check her results (in the first task she miscalculated the answer and corrected it on the spot).

Both Emma and Nora were able to interpret and produce mathematical texts. They both had difficulties with reading the table (Nora had difficulties until the end) and understanding the second task (for which Emma needed help from friends). Eventually, they understood what was given and asked. Formulating and solving calculations were easy to them. They had similar confidence in different parts of solving the tasks (see Table 2). Nora's feelings changed on a larger scale, though, ending up feeling slightly more confident than Emma. 
Table 2 Emma's and Nora's confidence with the tasks. The values are given on a scale o-10, o indicating the negative and 10 the positive end of the scale (see Figure 1)

\begin{tabular}{cccc}
\hline & $\begin{array}{c}\text { Where were you after } \\
\text { reading the task? }\end{array}$ & $\begin{array}{c}\text { Where were you while } \\
\text { solving the task? }\end{array}$ & $\begin{array}{c}\text { Where were you after solving } \\
\text { the task? }\end{array}$ \\
\hline Task 1 & & & 7,25 \\
Emma & 5,5 & 5,0 & 7,5 \\
Nora & $8,5 / 3,5$ (table) & 4,5 & 7,0 \\
Task 2 & & & 7,75 \\
Emma & 3,75 & 6,25 & 6,5 \\
Nora & 2,0 & & \\
\hline
\end{tabular}

Most of the time in their interviews, Emma and Nora were able to express their thoughts unambiguously and justify their actions. At some point, however, Emma had problems in explaining her thinking understandably and justifying her decision to calculate the overall distance of the trip in the second task. Neither of the girls was aware of their own thinking during problem solving processes. The video camera motivated them to solve the problems (extrinsic motivation). However, being able to do the tasks also motivated Emma (intrinsic motivation). Whereas Emma's answers were correct, Nora's answers were incorrect (task 1) or incomplete (task 2).

\subsection{Affect related to mathematics}

Emma sees mathematics as something that is very much tight to school subject: Mathematics is calculations, mathematical knowledge is gained through calculating, correctness of mathematical knowledge can be verified by asking the teacher, mathematics outside school is doing homework and reading for tests, and so forth. She recognizes that mathematics is useful and needed for instance to get a good job but she does not know how it is useful, just that it is. From school subjects, mathematics is needed in civics (stocks), chemistry and physics. All in all, it seems hard for Emma to see connections between mathematics and the real world.

For Nora, it is easy to see connections between mathematics and real world. First of all, mathematics plays a big role in science (philosophy, physics and chemistry). In addition to a tool view (doing investigations, calculations and demonstrations), Nora has also an idea of how mathematics as science develops (developing formulas, getting more accurate results and making new formulas). Secondly, Nora finds connections between mathematics and her world (baking and shopping). Finding mathematics in other school subjects is quite easy for her as well (physics, chemistry, geometry (maps) and history (eras)). For Nora, the meaning of mathematics is offering confidence; 'If you can calculate something is true, you can believe it'.

Both girls worked in a sustained and focused manner with the tasks. Nora is more confident in mathematics (Table 3) and takes a bigger responsibility of her own learning than Emma. Emma relates her success in mathematics to her teachers, their teaching styles and how they made her feel towards mathematics from first to ninth grade. Her grades in mathematics tests have varied substantially (6-9) over the years. 
Table 3 Emma's and Nora's confidence in school mathematics. The values are given on a scale o10, $\mathrm{o}$ indicating the negative and 10 the positive end of the scale (see Figure 1)

\begin{tabular}{lccc} 
& \multicolumn{2}{c}{ Where are you now in mathematics? } \\
& Interview 1 & (Interview 2) & (Interview 3) \\
\hline Emma & 6,25 & 5,5 & 5,5 \\
Nora & 7,75 & 8,25 & 7,25 \\
\hline
\end{tabular}

Emma and Nora are quite emotional when it comes to mathematics. Emma likes mathematics and is motivated to learn it. The feeling of success and being proud of herself motivates Emma to learn more mathematics. Nora starts the interview by saying that she likes mathematics very much and is the only one in her class who is really looking forward to math classes. She is also motivated to learn mathematics but her main reason for it is more traditional: She wants to get a good grade.

\section{Discussion}

Emma and Nora were selected for this paper because they have similar achievement level. However, the results introduce pupils that have different competences in mathematics. While Emma is more competent in problem solving, Nora is more confident, she can express her thinking better (more unambiguously), her view on mathematics is broader (application, or a tool view), she can connect mathematics to real world more easily and seems to take a bigger responsibility of her own learning than Emma.

All the above mentioned features are part of the curriculum and important aspects of mathematical thinking. Nevertheless, only problem solving is part of pupils' finalassessment criteria described in the Finnish curriculum. Based on the findings that Emma seems more fluent in problem solving and Nora is more confident and has a better grade in mathematics, a question arises: What is the role of non-measurable aspects of the curriculum in pupil evaluations? A draft version of new curriculum in Finland (will be implemented as of autumn 2016) suggests that even though pupil's motivation, positive self-image and self-confidence will not influence pupil evaluation, taking responsibility of own learning, expressing mathematical thinking and applying mathematics in different environments will be part of final-assessment criteria (FNBE, 2014). Thus, it seems that mathematical thinking will be evaluated in a more diverse way in the future.

This brings us to another question: How will the new criteria be evaluated in a fair way to all pupils? Recent research on pupils' learning results revealed how Finnish teachers seem evaluate their pupils comparing them with other pupils they teach (Rautopuro, 2013). This might also partly explain why Nora has a better grade in mathematics even though Emma seems more fluent in problem solving: Nora's class could be described as low achieving whereas Emma's class had pupils from all achievement levels (based on the researcher's observations). Whatever the reason is to the (small) difference in Emma and Nora's grades, this issue deserves more attention. Especially since the new curriculum seems to appreciate mathematical thinking in a broader way and is adding aspects to the evaluation criteria that are not based only on pure mathematics. 
The results presented in this paper serve as a starting point for studying pupils' mathematical thinking at the end of comprehensive school in Finland. In future, we will continue studying Emma and Nora to see if their results remain similar when their problem solving and affect is studied with more PISA tasks and interview themes (see more about interview themes in Viitala, 2013). Additionally, we will compare the results of all 8 pupils who participated in this research project and ask what characterises the mathematical thinking of these pupils near the end of comprehensive school. As we go further, we also hope to find indications on the relationship of cognition and affect in mathematical thinking (cf. Vinner, 2004; Zan et al., 2006).

\section{References}

Burton, L. (1984). Mathematical thinking: The struggle for meaning. Journal for Research in Mathematics Education, 15(1), 35-49.

Doerr, H. M. (2006). Examining the tasks of teaching when using students' mathematical thinking. Educational Studies in Mathematics, 62(1), 3-24.

FNBE. (2004). National core curriculum for basic education. Finnish National Board of Education. Retrieved November 28 2014, from http://www.oph.fi/english/curricula_and_qualifications/basic_education

FNBE. (2014). Perusopetuksen opetussuunnitelman perusteet: Opetus vuosiluokilla 7-9. [National core curriculum for basic education: Teaching in grades 7-9.] Finnish National Board of Education. Draft 19.9.2014. Retrieved November 28 2014, from http://www.oph.fi/download/160362_opsluonnos_perusopetus_vuosiluokat_7_9_19092014.pdf

Hannula, M. S. (2011). The structure and dynamics of affect in mathematical thinking and learning. In M. Pytlak, T. Rowland \& E. Swoboda (Eds.) Proceedings of the Seventh Congress of the European Society for Research in Mathematics Education (pp. 34-6o). Poland: University of Rzesów.

Hannula, M. S. (2012). Exploring new dimensions of mathematics-related affect: Embodied and social theories. Research in Mathematics Education, 14(2), 137-161.

Hirvonen, K. (2012). Onko laskutaito laskussa? Matematiikan oppimistulokset peruskoulun päättövaiheessa 2011 [Are skills to calculate declining? Learning results in mathematics at the end of comprehensive school in 2011]. Koulutuksen seurantaraportit 2014:4. Helsinki: Opetushallitus.

Hähkiöniemi, M. (2006). The role of representations in learning the derivative. University of Jyväskylä, Department of mathematics and statistics, report 104.

Joutsenlahti, J. (2005). Lukiolaisen tehtäväorientoituneen matemaattisen ajattelun pïrteitä [Characteristics of task-oriented mathematical thinking among students in upper-secondary school]. Acta Universitatis Tamperensis 1061. University of Tampere.

Kantowski, M. G. (1980). Some thoughts on teaching for problem-solving. In NCTM Yearbook 1980, (pp. 195-203). Reston (VA): Council.

Kvale, S. \& Brinkmann, S. (2009). InterViews, (2nd ed.) London: Sage.

McGregor, D. (2007). Developing thinking, developing learning: A guide to thinking skills in education. Maidenhead: Open University Press.

Merenluoto, K. (2001). Lukiolaisen reaaliluku: Lukualueen laajentaminen käsitteellisenä muutoksena matematiikassa [Students' real number: Enlargement of the number concept as a conceptual change in mathematics]. University of Turku, series C, part 176. 
Mullis, I. V. S., Martin, M. O., Foy, P., \& Arora, A. (2012). TIMSS 2011 international results in mathematics. Boston: TIMSS \& PIRLS International Study Center, Boston College.

OECD (2006). Assessing scientific, reading and mathematical literacy: A framework for PISA 2006. Paris: OECD.

OECD (2009). PISA 2009 assessment framework. key competencies in reading, mathematics and science. Paris: OECD.

OECD (2014). PISA 2012 results: What students know and can do - Student performance in mathematics, reading and science (Volume I, Revised edition, February 2014). Paris: OECD.

Pehkonen, E. (1995). Pupils' view of mathematics: Initial report for an international comparison project. University of Helsinki, Department of teacher education. Research report 152.

Polya, G. (1957). How to solve it. Princeton, NJ: Lawrence Erlbaum.

Rautopuro J. (Ed.) (2013). Hyödyllinen pakkolasku. Matematiikan oppimistulokset peruskoulun päättövaiheessa 2012 [Useful forced landing. Learning results in mathematics at the end of comprehensive school in 2012]. Koulutuksen seurantaraportit 2013:3. Helsinki: Opetushallitus.

Schoenfeld, A. H. (1987). What's all the fuss about metacognition? In A. H. Schoenfeld (Ed.) Cognitive science and mathematics education, (pp. 189-215). Hillsdale, NJ: Erlbaum.

Sternberg, R. (1996). What is mathematical thinking? In R. Sternberg \& T. Ben-Zeev (Eds.) The nature of mathematical thinking, (pp. 303-318). Mahwah, NJ: Erlbaum.

Stillman, G. \& Mevarech, Z. (2010). Metacognition research in mathematics education: From hot topic to mature field. $Z D M, 42(2), 145-148$.

Törner, G., Schoenfeld, A. H. \& Reiss, K. M. (2007). Problem Solving Around the World: Summing Up the State of the Art. $Z D M, 39(5-6)$, p. 353.

Viitala, H. (2013). Alex's world of mathematics. In M. S. Hannula, P. Portaankorva-Koivisto, A. Laine \& L. Näveri (Eds.) Current state of research on mathematical beliefs XVIII: Proceedings of the MAVI-18 Conference, September 12-15, 2012, Helsinki, Finland (pp. 71-82). Publications in Subject Didactics 6. Helsinki: The Finnish Research Association for Subject Didactics.

Vinner, S. (2004). Mathematical thinking, values and theoretical framework. In M. J. Høines \& A. B. Fuglestad (Eds.) Proceedings of the $28^{\text {th }}$ Conference of the International Group for the Psychology of Mathematics Education (Vol 1, pp. 126-127). Bergen, Norway: Bergen university college.

Välijärvi, J. (2014). Osaaminen kestävällä perustalla - Suomen PISA-tulosten kehitys vuosina 200O-2009 (Tilannekatsaus helmikuu 2014) [Know-how on solid ground - The development of Finnish PISA results in 2000-2009 (Review in February 2014)]. Memos 2014:1. Retrieved November 28 2014, from http://www.oph.fi/julkaisut/2014/osaaminen_kestavalla_perustalla

Zan, R., Brown, L., Evans, J. \& Hannula, M. S. (2006). Affect in Mathematics Education: An introduction. Educational Studies in Mathematics, 63(2), 113-121. 